\title{
Effect of Thrombin on Calcium Homeostasis in Chick Embryonic Heart Cells Receptor-operated Calcium Entry with Inositol Trisphosphate and a Pertussis Toxin-sensitive G Protein as Second Messengers
}

Walter W. Chien, Rajendra Mohabir, and William T. Clusin

Division of Cardiology, Falk Cardiovascular Research Center, Stanford University School of Medicine, Stanford, California 94305

\begin{abstract}
Thrombin increases intracellular calcium $\left(\left[\mathrm{Ca}^{++}\right]_{i}\right)$ in several cell types and causes a positive inotropic effect in the heart. We examined the mechanism of the thrombin-induced $\left[\mathrm{Ca}^{++}\right]_{\mathrm{i}}$ increase in chick embryonic heart cells loaded with the fluorescent calcium indicator, indo-1. Thrombin $(1 \mathrm{U} / \mathrm{ml})$ increased both systolic and diastolic $\left[\mathrm{Ca}^{++}\right]_{\text {if }}$ from $617 \pm 62$ and $324 \pm 46$ to $1041 \pm 93$ and $587 \pm 38 \mathrm{nM}$, respectively. An initial rapid $\left[\mathrm{Ca}^{++}\right]_{i}$ increase was followed by a more sustained increase. There were associated increases in contraction strength, beat frequency, and action potential duration. The $\left[\mathrm{Ca}^{++}\right]_{i}$ increase was not blocked by tetrodotoxin or verapamil, but was blocked by pretreatment with pertussis toxin $(100 \mathrm{ng} / \mathrm{ml})$. The thrombininduced $\left[\mathrm{Ca}^{++}\right]_{i}$ increase was partly due to intracellular calcium release, since it persisted after removal of external calcium. The $\left[\mathrm{Ca}^{++}\right]_{i}$ increase in zero calcium was more transitory than in normal calcium and was potentiated by $10 \mathrm{mM} \mathrm{Li}$. Thrombin also induced influx of calcium across the surface membrane, which could be monitored using $\mathrm{Mn}^{++}$ions, which quench indo-1 fluorescence when they enter the cell. Thrombin-induced $\mathrm{Mn}^{++}$entry was insensitive to verapamil, but was blocked by $2 \mathrm{mM} \mathrm{Ni}{ }^{++}$. Thrombin increased inositol trisphosphates by $180 \%$ at $90 \mathrm{~s}$ and this effect was also blocked by pretreatment with pertussis toxin. Conclusion: thrombin promotes calcium entry and release in embryonic heart cells even when action potentials are inhibited. Both modes of $\left[\mathrm{Ca}^{++}\right]_{i}$ increase may be coupled to the receptor by pertussis toxinsensitive G proteins. (J. Clin. Invest. 1990. 85:1436-1443.) signal transduction • ion channels • contraction strength • membrane potential • indo-1.
\end{abstract}

\section{Introduction}

Thrombin is an important proteolytic enzyme in the coagulation cascade. It is also a potent stimulus for platelet aggregation and a mitogen in a variety of cell types (1). Thrombin has been shown to increase intracellular calcium in platelets and smooth muscle cells $(2,3)$. Recently, it has been suggested that calcium can enter cells by a receptor-mediated pathway (4), and that this may be a possible mechanism for thrombin-in-

Address reprint requests to Dr. Clusin, Division of Cardiology, Falk Cardiovascular Research Center, Stanford University School of Medicine, Stanford, CA 94305.

Received for publication 25 August 1989 and in revised form 12 December 1989.

J. Clin. Invest.

(c) The American Society for Clinical Investigation, Inc. $0021-9738 / 90 / 05 / 1436 / 08 \quad \$ 2.00$

Volume 85, May 1990, 1436-1443 duced calcium entry in platelets. Thrombin has also been shown to activate phospholipase $\mathrm{C}$ and to stimulate formation of inositol phosphates, which can mobilize calcium release from endoplasmic reticulum (5). The activation of phospholipase $\mathrm{C}$ may be mediated by a family of intracellular signal transducer proteins known as $G$ proteins $\left(G_{p}\right)(6)$. Indeed, it is thought that activation of phospholipase $C$ by thrombin in smooth muscle may be coupled to a pertussis toxin-sensitive $G$ protein (2).

The effect of thrombin on cardiac cells is less well studied. Recently, thrombin has been shown to have a positive inotropic effect in the heart which has been ascribed to stimulation of the voltage-dependent calcium current (7). To further clarify this phenomenon, we studied the effect of thrombin on calcium transients in chick embryonic heart cells and correlated these effects with changes in the action potential and contraction. We found that thrombin causes elevation of $\left[\mathrm{Ca}^{++}\right]_{i}$ transients and promotes entry of divalent cations across the surface membrane. Thrombin also causes release of calcium from intracellular stores. All of these processes may be linked to a pertussis toxin-sensitive $G$ protein, and to stimulation by thrombin of inositol trisphosphate $\left(\mathrm{IP}_{3}\right)^{1}$ synthesis. The pathway for divalent cation influx was blocked by nickel ( $2 \mathrm{mM}$ ), but was not blocked by verapamil, even at concentrations sufficient to inhibit beat-to-beat calcium transients. These observations suggest that thrombin activates calcium influx through a receptor-operated channel.

\section{Methods}

Materials. Myo- $\left[{ }^{3} \mathrm{H}\right]$ inositol was purchased from DuPont-New England Nuclear (Wilmington, DE), indo-1 AM (acetoxymethyl ester) from Molecular Probes Inc. (Junction City, OR), Dowex resin (AG 1-X8 formate) from Bio-Rad Laboratories (Richmond, CA). All other chemicals were purchased from Sigma Chemical Co. (St. Louis, MO). Highly purified human $\alpha_{2}$-thrombin was a generous gift from Dr. Marc Shuman (University of California, San Francisco).

Cell culture. Ventricles from 10-14-d-old chick embryos were removed by sterile dissection. Myocardial cells were dissociated using multiple-cycle trypsinization as described previously (8). The dissociated cells were seeded at $10^{6} \mathrm{cells} / \mathrm{ml}$ in Sykes-Moore chambers (Bellco Glass, Inc., Vineland, NJ), the bottoms of which were coated with a layer of hydrophobic resin (Sylgard, Dow Corning Corp., Midland, MI) that prevents attachment of cells. Spontaneously beating cell aggregates were formed after 2-3 d in culture. Experiments were performed on aggregates 3-5 $d$ in culture.

Measurement of $\left[\mathrm{Ca}^{++}\right]_{i}$. Cell aggregates were loaded with indo-1 - $\mathrm{AM}(10 \mu \mathrm{M})$ as described previously (9). Experiments were performed in Hepes-buffered physiological saline which contained $137 \mathrm{mM} \mathrm{NaCl}$, $2.7 \mathrm{mM} \mathrm{KCl}, 0.4 \mathrm{mM} \mathrm{NaH}_{2} \mathrm{PO}_{4}, 1.0 \mathrm{mM} \mathrm{MgCl}_{2}, 1.8 \mathrm{mM} \mathrm{CaCl}_{2}, 5.5$ $\mathrm{mM}$ dextrose, and $6 \mathrm{mM}$ Hepes, adjusted to $\mathrm{pH}$ 7.4. In experiments

1. Abbreviations used in this paper: $\mathrm{IP}_{3}$, insitol trisphosphate; $\mathrm{PPACK}$, D-phenylalanyl-prolyl-arginyl chloromethyl ketone. 
without external calcium, the buffer was changed to one that contained zero $\mathrm{Ca}^{++}$and $2 \mathrm{mM}$ EGTA. Aggregates were placed in a 5-ml nonfluorescent chamber on the stage of an inverted microscope where all fluorescence measurements were made. Drugs and test solutions were added to the surface of the bath using a pipette and diffused to reach the cell aggregate at the bottom of the bath. The selected cell aggregate was centered and was the only object in the optical field. The cells were illuminated by a 100-W ultraviolet source (E. Leitz Inc., Rockleigh, $\mathrm{NJ}$ ) filtered at $360 \pm 5 \mathrm{~nm}$ (Corion Corp., Holliston, MA) and directed through a $\times 20$ objective. Fluorescence emissions were collected by the objective and directed through a beamsplitter into two photomultipliers fitted with optical bandpass filters centered at 400 and $550 \mathrm{~nm}$. The output of the photomultipliers was passed into an electronic ratio circuit so that the fluorescence ratio, $F_{400} / F_{550}$, could be obtained. In experiments involving the monitoring of $\mathrm{Mn}^{++}$entry, a 430-nm filter was used. This wavelength was chosen because it represents the in vivo isosbestic wavelength of indo-1 (10). Entry of $\mathrm{Mn}^{++}$can fully quench the $430-\mathrm{nm}$ indo-1 emissions, but changes in $\left[\mathrm{Ca}^{++}\right]_{\mathrm{i}}$ do not affect fluorescence. Calibration of the indo-1 fluorescence was performed as reported previously (11) by exposing the cell aggregates to a calciumsaturating $\left(20 \mathrm{mM} \mathrm{CaCl}_{2}\right)$ and then a manganese-saturating $(20 \mathrm{mM}$ $\mathrm{MnCl}_{2}$ ) solution in the presence of ionomycin $(150 \mathrm{nM}), \mathrm{a} \mathrm{Ca}^{++}$and $\mathrm{Mn}^{++}$ionophore to allow measurement of $F_{\max }$ and $F_{\min }$, respectively, at $F_{400}(9,11) . F_{\min }$ was given by the equation: $F_{\min }=F_{\mathrm{Mn}^{++}}+0.18$ $\left(F_{\max }-F_{\mathrm{Mn}^{++}}\right)$where $F_{\mathrm{Mn}^{++}}$is the fluorescence measured in the presence of $\mathrm{MnCl}_{2}$ and 0.18 is a factor determined from measurements in cuvettes (12). The concentration of intracellular free calcium, $\left[\mathrm{Ca}^{++}\right]_{i}$, was obtained according to Tsien et al. (13): $\left[\mathrm{Ca}^{++}\right]_{\mathrm{i}}=K_{\mathrm{d}}\left(F-F_{\min }\right) /$ $\left(F_{\max }-F\right)$, where $F$ is the cellular fluorescence recorded at $F_{400}$, and $K_{\mathrm{d}}$ is $250 \mathrm{nM}$. The above calibration procedure is advantageous in cells loaded with indo-1 AM, since incomplete de-esterification of indo-1 AM within the cytoplasm would alter the $F_{400} / F_{550}$ ratio, but would not affect the calibration procedure described above. The exact value of the $F_{400} / F_{550}$ ratio varies in our experiments as a result of variable gain settings that were built into the ratio circuit. For this reason, the exact value of the $F_{400} / F_{550}$ ratio has no physical meaning. The concentration of thrombin used in all the experiments was $1 \mathrm{U} / \mathrm{ml}$. There was some variability in the extent of the thrombin-induced $\left[\mathrm{Ca}^{++}\right]_{i}$ increase in different batches of cells. Thus, experiments involving modification of the thrombin response were done using control cells from the same batch.

Intracellular recordings. Microelectrodes were made from fiberfilled glass capillaries filled with $3 \mathrm{M} \mathrm{KCl}$ and had tip resistances of 20-50 M $\Omega$. Microelectrode recordings were made from the same aggregate where calcium transients were recorded. Action potential recordings were displayed on a dual-beam oscilloscope (Tektronix Inc., Beaverton, OR) and recorded by a strip chart recorder (Brush 2400 S, Gould Inc., Cleveland, OH).

Mechanical recordings. Cell edge movements were recorded with a video edge detector (Crescent Electronics, Sandy, UT) as previously described (11). The analog voltage output from the motion detector was calibrated to indicate micrometers of edge motion. The motion signals were recorded by a strip chart recorder (Gould Inc.).

Measurement of inositol phosphate production. Cell aggregates of day 2 in culture were pooled into vials at a concentration of $1-2 \times 10^{6}$ cells/ml and labeled with myo- $\left[{ }^{3} \mathrm{H}\right]$ inositol $(2 \mu \mathrm{Ci} / \mathrm{ml})$ overnight. The labeling was improved by reducing the fetal calf serum in the culture medium to $0.3 \%$ during labeling. In some experiments, the cells were treated with pertussis toxin $(100 \mathrm{ng} / \mathrm{ml})$ for $6 \mathrm{~h}$ before the addition of thrombin. The cells were incubated with $\mathrm{Li}^{+}(10 \mathrm{mM})$ for $10 \mathrm{~min}$ at the start of the experiment. After exposure of the cells to thrombin (1 $\mathrm{U} / \mathrm{ml}$ ), inositol phosphates were extracted and separated by anion exchange chromatography $(14,15)$ and then eluted with a gradient of formate solutions. The column was washed with $8 \mathrm{ml}$ of $\mathrm{H}_{2} \mathrm{O}$ and then eluted sequentially with $5 \mathrm{mM}$ sodium tetraborate: $150 \mathrm{mM}$ sodium formate, $100 \mathrm{mM}$ formic acid: $300 \mathrm{mM}$ ammonium formate, and 100 $\mathrm{mM}$ formic acid: $1 \mathrm{M}$ ammonium formate to obtain fractions containing $\mathrm{IP}_{1}, \mathrm{IP}_{2}$, and $\mathrm{IP}_{3}$ respectively. All fractions were counted in a liquid scintillation counter. $\mathrm{IP}_{3}$ as defined by this method, actually consists of inositol 1,3,4-tris-, 1,4,5,-tris-, and 1,3,4,5-tetrakisphosphate (16). This procedure gave rise to some variability in the basal release of inositol phosphates (2), which may be due to variations in cell numbers and efficiency of myo- $\left[{ }^{3} \mathrm{H}\right]$ inositol incorporation. Therefore, each experiment was internally controlled. $\mathrm{IP}_{3}$ was determined as counts per minute $(\mathrm{cpm})$ per $\mathrm{mg} / \mathrm{ml}$ of protein and each experimental value was expressed as a percentage of the corresponding control value. Protein determination was done according to the Lowry method (17).

Data are presented as the mean \pm standard error. Comparisons were made using the paired or unpaired two-tailed Student's $t$ test.

\section{Results}

Effect of thrombin on $\left[\mathrm{Ca}^{++}\right]_{i}$. Chick embryonic heart cell aggregates loaded with indo- 1 exhibit $\left[\mathrm{Ca}^{++}\right]_{i}$-dependent fluorescence transients. Addition of thrombin causes a significant rise in both the systolic and diastolic level of the transients (Fig. 1). This rise begins, on the average, $35.0 \pm 4.5 \mathrm{~s}(n=7)$ after the addition of thrombin and peaks about $20 \mathrm{~s}$ later (Fig. 2). The peak is followed by a slow decay which leaves $\left[\mathrm{Ca}^{++}\right]_{i}$ significantly elevated $80 \mathrm{~s}$ after the response begins. Thrombin causes the peak systolic $\left[\mathrm{Ca}^{++}\right]_{i}$ to increase from $617 \pm 62$ to $1041 \pm 93 \mathrm{~nm}$ and diastolic $\left[\mathrm{Ca}^{++}\right]_{\mathrm{i}}$ to increase from $324 \pm 46$ to $587 \pm 38 \mathrm{~nm}(n=6, P<0.005)$. The systolic $\left[\mathrm{Ca}^{++}\right]_{\mathrm{i}}$ increases more rapidly than the diastolic value, so that the net amplitude of the $\left[\mathrm{Ca}^{++}\right]_{\mathrm{i}}$ transient also becomes larger. These effects appear to require the proteolytic activity of thrombin as D-phenylalanyl-prolyl-arginyl chloromethyl ketone, (PPACK, 1 $\mu \mathrm{M})$, which is known to bind to the active site of thrombin (18), totally prevents the effect on $\left[\mathrm{Ca}^{++}\right]_{i}$ (Fig. 3).

Consistent with the rise in $\left[\mathrm{Ca}^{++}\right]_{i}$, thrombin also has a positive inotropic effect as measured by cell edge movement. Mean edge movement increases from $12.3 \pm 1.2$ to $13.1 \pm 1.4 \mu \mathrm{m}$

A

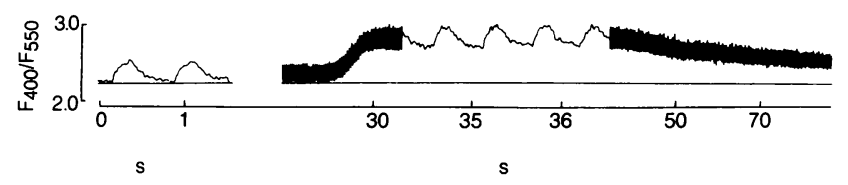

B

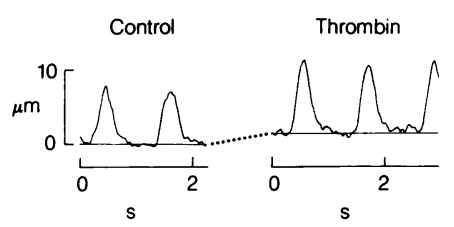

Figure 1. $(A)$ Thrombin-induced elevation of calcium transients in embryonic heart cells. Thrombin $(1 \mathrm{U} / \mathrm{ml})$ caused a sustained elevation of the systolic and diastolic levels of the calcium transients. The net amplitude of the transients and the beat frequency also increased. Similar results were obtained in seven other experiments. Exact values of the calcium sensitive fluorescence ratio $\left(F_{400} / F_{550}\right)$ are arbitrary, since they are determined by the optical system and amplifier gains. $(B)$ Effect of thrombin on cell edge displacement. Thrombin increased edge displacement during systole, and caused less complete relaxation during diastole. Net edge displacement during each beat also increased significantly. 


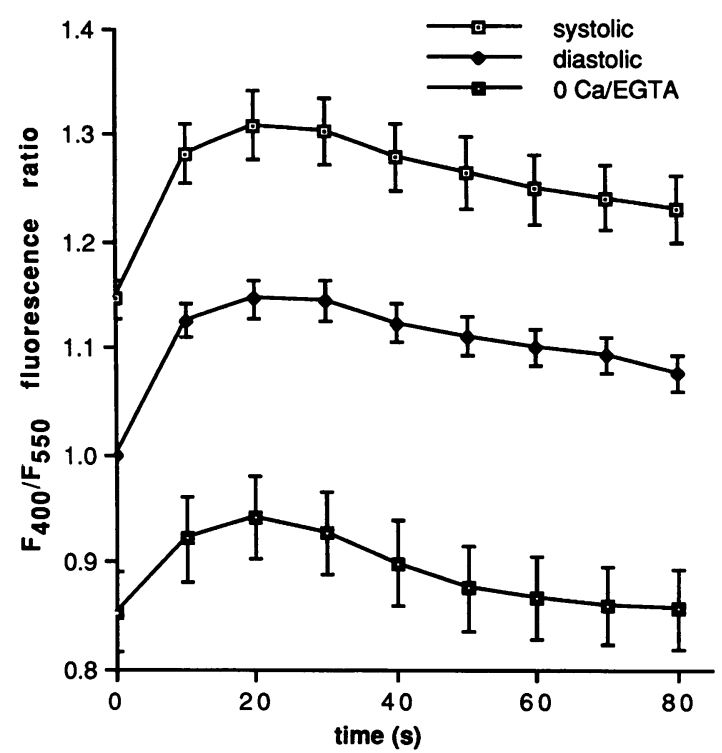

Figure 2. Time course of the $\left[\mathrm{Ca}^{++}\right]_{\mathrm{i}}$ increase induced by thrombin $(1 \mathrm{U} / \mathrm{ml})$ in the presence $\left(1.8 \mathrm{mM} \mathrm{Ca}^{++}, n=7\right)$ or in the absence (zero $\mathrm{Ca}^{++} / 2 \mathrm{mM}$ EGTA, $n=3$ ) of external calcium. $F_{400} / F_{550}$ fluorescence ratios were normalized to the end-diastolic value of calcium transients at the start of each experiment. Time zero was taken as the onset of the thrombin-induced $\left[\mathrm{Ca}^{++}\right]_{i}$ increase. Cells were pretreated with $10 \mathrm{mM} \mathrm{Li}^{+}$in the experiments without external calcium. The magnitude of the $\left[\mathrm{Ca}^{++}\right]_{i}$ increase was smaller and the time course less sustained in the absence of external calcium.

( $n=16, P=0.003$ ). An example is shown in Fig. $1 B$. With the addition of thrombin, there is a significant increase in systolic and end-diastolic edge displacement as well as an increase in the net amplitude of each beat. Thrombin also causes an associated increase in beat frequency from $108 \pm 8.7$ to $121 \pm 8.6$ beats/min $(n=8, P=0.0005)$. There is no significant change in end-diastolic membrane potential on exposure to thrombin. However, thrombin causes a significant increase in the action potential duration measured at $50 \%$ of repolarization from $132.0 \pm 8.2$ to $137.6 \pm 8.5 \mathrm{~ms}(n=5, P=0.009)$.
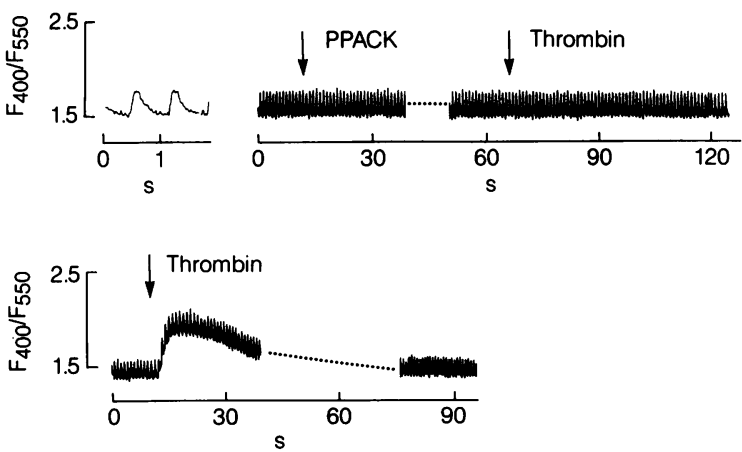

Figure 3. Effect of PPACK on the thrombin-induced $\left[\mathrm{Ca}^{++}\right]_{i}$ in crease. In the top trace, exposure to PPACK $\left(10^{-6} \mathrm{M}\right.$, first arrow), caused no significant change in the calcium transient. The effect of thrombin, added $30 \mathrm{~s}$ later (second arrow), was completely blocked. The bottom trace shows the same experiment after washout of PPACK. Thrombin caused marked elevation of the calcium transients in the absence of PPACK.
Effect of thrombin on $I P_{3}$ synthesis. Thrombin has been shown to stimulate $\mathrm{IP}_{3}$ synthesis in a variety of cell types including chick embryonic heart cells (19-22) and $\mathrm{IP}_{3}$ is known to be an important second messenger in mediating internal calcium release (23). To demonstrate the involvement of the $\mathrm{IP}_{3}$ pathway in mediating the $\left[\mathrm{Ca}^{++}\right]_{i}$ increase, we have measured $\mathrm{IP}_{3}$ production after the addition of thrombin. Cells are incubated with myo- $\left[{ }^{3} \mathrm{H}\right]$ inositol overnight as described in Methods. At the start of experiments, cells are incubated with $\mathrm{Li}^{+}(10 \mathrm{mM})$ for $10 \mathrm{~min}$. $\mathrm{Li}^{+}$has been shown to inhibit the recycling of inositol phosphates and enhance the accumulation of $\operatorname{IP}_{3}(15,24)$. Thrombin is added at time zero and experiments are terminated by addition of $10 \mathrm{ml}$ of $10 \%$ trichloroacetic acid at the time indicated to extract membrane lipids. Results are expressed as percentages of basal $\mathrm{IP}_{3}$ synthesis in experiments done on the same day and on the same batch of cells in the absence of thrombin. As shown in Fig. 4, thrombin causes a significant rise in $\mathrm{IP}_{3}$ production to about $180 \%$ of baseline. The rise in $\mathrm{IP}_{3}$ occurs between 30 and $90 \mathrm{~s}$ after the addition of thrombin and starts to decline by $120 \mathrm{~s}$.

Effect of pertussis toxin pretreatment on thrombin-induced $I_{3}$ production and $\left[\mathrm{Ca}^{++}\right]_{i}$. Chick embryonic heart cells have been shown to contain a number of different $G$ proteins (14, $25,26)$. In other cell types, thrombin activates phospholipase $\mathrm{C}$ by stimulating a $\mathrm{G}$ protein that is sensitive to pertussis toxin (2). We therefore examined the role of $G$ proteins in mediating the $\left[\mathrm{Ca}^{++}\right]_{\mathrm{i}}$ increase by pretreating the cells with pertussis toxin $(100 \mathrm{ng} / \mathrm{ml})$ for $6 \mathrm{~h}$ before the addition of thrombin. This pretreatment does not noticeably affect the contractions of the cells and they exhibit similar calcium transients to those of control cells. Fig. 5 summarizes six experiments performed on cells pretreated with pertussis toxin. In these cells, the thrombin-induced increase in both systolic and diastolic $\left[\mathrm{Ca}^{++}\right]_{i}$ is

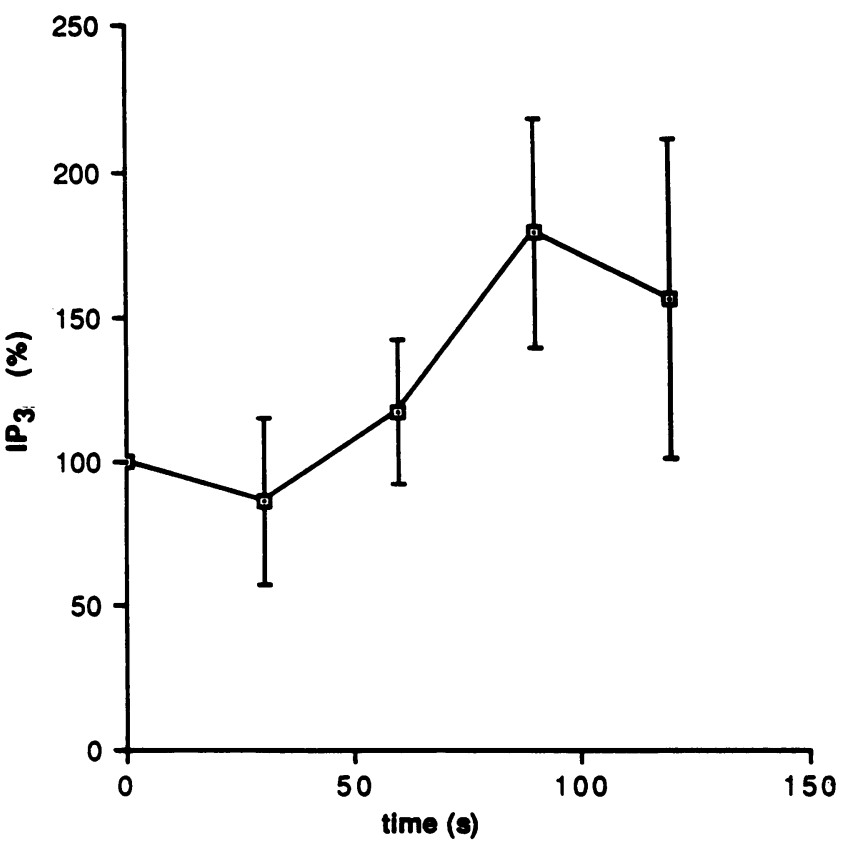

Figure 4. Thrombin-induced $\mathrm{IP}_{3}$ synthesis. Cells were stimulated with $1 \mathrm{U} / \mathrm{ml}$ thrombin at time $0 . \mathrm{IP}_{3}$ was measured as described under "methods". $\mathrm{IP}_{3}$ peaked $90 \mathrm{~s}$ after addition of thrombin and differed significantly from the baseline level $(n=12, P<0.05)$. 


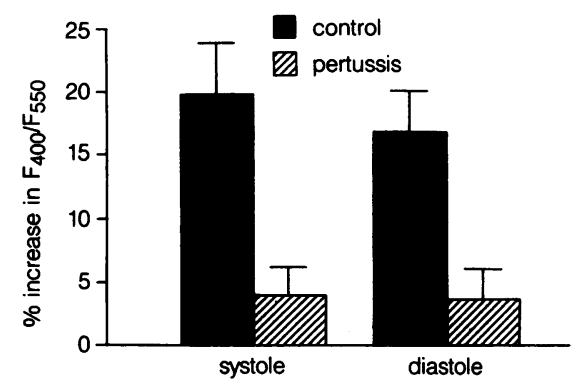

Figure 5. Inhibition of the thrombin-induced $\left[\mathrm{Ca}^{++}\right]_{\mathrm{i}}$ increase by pertussis toxin. Cells were pretreated with pertussis toxin $(100 \mathrm{ng} / \mathrm{ml})$ for $6 \mathrm{~h}$ where indicated $(n=6)$. The thrombin-induced $\left[\mathrm{Ca}^{++}\right]_{i}$ increase was significantly reduced $(P<0.006)$ compared to control $(n=8)$.

significantly reduced compared to cells not treated with pertussis toxin.

We also examined the effect of pertussis toxin on thrombin-induced $\mathrm{IP}_{3}$ formation. Cells are again pretreated with pertussis toxin for $6 \mathrm{~h}$ before the addition of thrombin. Fig. 6 is a summary of five such experiments. Thrombin-stimulated $\mathrm{IP}_{3}$ synthesis is significantly reduced 60 and $90 \mathrm{~s}$ after the addition of thrombin. These experiments suggest that a pertussis toxinsensitive $G$ protein is involved in the thrombin-mediated $\left[\mathrm{Ca}^{++}\right]_{\mathrm{i}}$ and $\mathrm{IP}_{3}$ increase.

Verapamil does not block the thrombin-induced $\left[\mathrm{Ca}^{++}\right]_{i}$ increase. Thrombin has been shown to stimulate the voltage-dependent calcium current (7) in frog ventricular cells, which may explain its positive inotropic effect. The possible involvement of L-type calcium channels in mediating the thrombininduced $\left[\mathrm{Ca}^{++}\right]_{\mathrm{i}}$ increase has been examined by pretreating the cells with $50 \mu \mathrm{M}$ verapamil. As shown in Fig. 7, within 2 min of exposure to verapamil, the cell aggregate stops beating and the calcium transients are abolished. Abolition of action potentials has been confirmed by simultaneous microelectrode

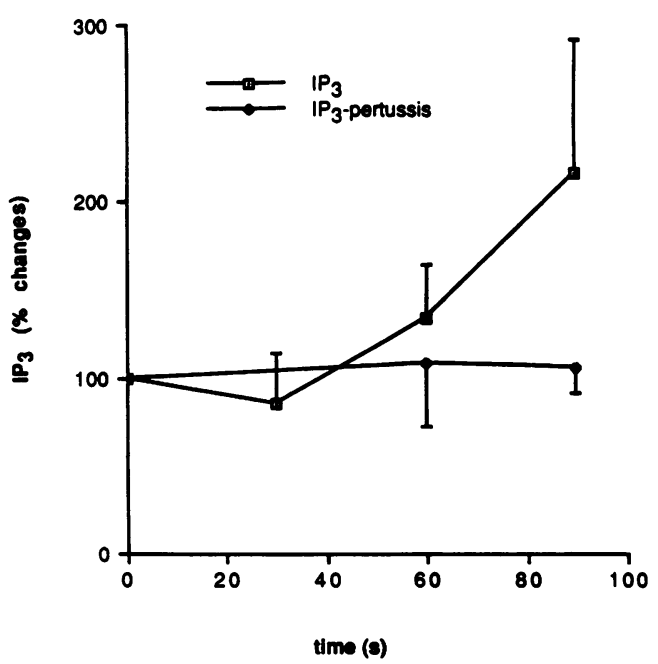

Figure 6. Inhibition of the thrombin-induced $\mathrm{IP}_{3}$ increase by pertussis toxin. Cells were pretreated with $100 \mathrm{ng} / \mathrm{ml}$ pertussis toxin for $6 \mathrm{~h}(n=5)$ before thrombin was added. $\mathrm{IP}_{3}$ was measured as described previously. The thrombin-induced $\mathrm{IP}_{3}$ increase was significantly reduced $(P<0.05)$ compared with cells not treated with pertussis toxin. recordings (data not shown). Addition of thrombin to verapamil-treated cell aggregates still elicits a $\left[\mathrm{Ca}^{++}\right]_{i}$ increase. Thus, inhibition of the L-type calcium channels does not block the effects of thrombin on $\left[\mathrm{Ca}^{++}\right]_{i}$. The verapamil-insensitive $\left[\mathrm{Ca}^{++}\right]_{\mathrm{i}}$ increase could be due to release of calcium from intracellular stores or to entry of calcium through a verapamil-insensitive pathway.

Thrombin-stimulated calcium entry. Experiments with $\mathrm{Mn}^{++}$in the external solution have been used by other investigators $(3,4,27)$ to provide evidence for agonist-induced $\mathrm{Ca}^{++}$ entry into cells. Since $\mathrm{Mn}^{++}$strongly quenches indo-1 fluorescence, an agonist-mediated decline in the fluorescence signal would suggest $\mathrm{Mn}^{++}$entry, presumably via channels normally used by $\mathrm{Ca}^{++}$. This is particularly evident in fluorescence emissions recorded at $430 \mathrm{~nm}$, which is the isosbestic wavelength of indo-1 (28). Fluorescence at $430 \mathrm{~nm}$ is insensitive to changes in $\left[\mathrm{Ca}^{++}\right]_{i}$, so that quenching of the $F_{430}$ signal can only be due to the entry of $\mathrm{Mn}^{++}$through a receptor-activated pathway. Fig. 8 shows an experiment in which fluorescence emissions are collected at 430 and $400 \mathrm{~nm}$. Initially, the $F_{400}$ signal shows calcium transients whereas $F_{430}$, being calciuminsensitive, does not. Verapamil $(50 \mu \mathrm{M})$ is then added which causes the cell aggregate to become quiescent and causes a decline of the $F_{400}$ signal with no change in the $F_{430}$ signal. Subsequent addition of $0.8 \mathrm{mM} \mathrm{Mn}^{++}$has no effect on either signal. However, addition of thrombin causes rapid quenching of both signals, compatible with $\mathrm{Mn}^{++}$entry into the cytosol. Quenching is progressive throughout the recording, which suggests that $\mathrm{Mn}^{++}$entry continues for at least $60 \mathrm{~s}$. Similar results are obtained when tetrodotoxin $(30 \mu \mathrm{M})$ is used instead of verapamil to abolish spontaneous beating (data not shown).

An interesting feature of the experiment in Fig. 8 is that there is no increase in the calcium-sensitive $F_{400}$ fluorescence signal before the $\mathrm{Mn}^{++}$-induced quenching effect. This result implies that thrombin-induced $\mathrm{Mn}^{++}$entry occurs early in relation to the $\left[\mathrm{Ca}^{++}\right]_{\mathrm{i}}$ increase. $\mathrm{Mn}^{++}$entry is not preceded, for example, by thrombin-induced calcium release. These results indicate that the verapamil insensitive $\left[\mathrm{Ca}^{++}\right]_{\mathrm{i}}$ increase occurs, at least in part, through thrombin-induced influx of divalent cations across the surface membrane. This thrombin-induced influx is not preceded by detectable release from internal stores.

Because a receptor-operated calcium channel has not been described in the heart, we sought to confirm whether thrombin-induced $\mathrm{Mn}^{++}$influx is truly independent of conventional calcium channels. To do this, we first determined whether verapamil blocks $\mathrm{Mn}^{++}$entry during $\mathrm{KCl}$ depolarization; and secondly, whether $\mathrm{KCl}$ depolarization blocks the subsequent action of thrombin. These experiments are performed in sodium-free tris buffer to prevent influx of calcium or $\mathrm{Mn}^{++}$by the sodium calcium exchange (29). In these experiments, the introduction of sodium-free tris buffer caused transient contracture secondary to calcium influx through the $\mathrm{Na}^{+} / \mathrm{Ca}^{++}$ exchange. Relaxation of the contracture is due to depletion of intracellular sodium, which prevents further entry of $\mathrm{Ca}^{++}$by $\mathrm{Na}^{+} / \mathrm{Ca}^{++}$exchange. Depolarization is produced by $60 \mathrm{mM}$ $\mathrm{KCl}$, which is known to cause calcium entry in the absence of verapamil (29), and also quenches the $F_{430}$ signal when $\mathrm{Mn}^{++}$ is present (not illustrated). In the presence of verapamil (50 $\mu \mathrm{M})$ and $\mathrm{Mn}^{++}(0.8 \mathrm{mM}), 60 \mathrm{mM} \mathrm{KCl}$ has no effect on the $F_{430}$ signal. This result confirms that depolarization-induced calcium influx is effectively blocked. However, subsequent expo- 


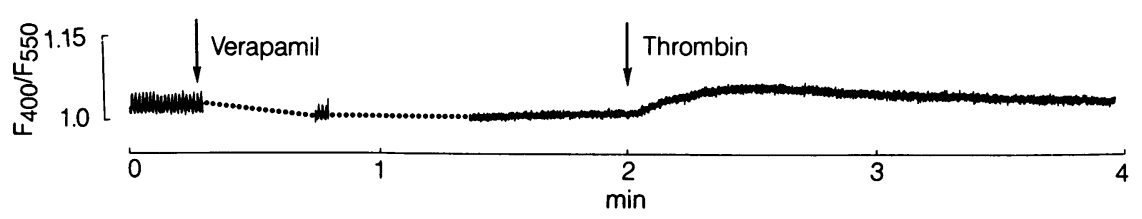

Figure 7. Thrombin-induced $\left[\mathrm{Ca}^{++}\right]_{\mathrm{i}}$ increase in the presence of verapamil $(50 \mu \mathrm{M})$. Verapamil caused cessation of beating and a slow decline in the calcium-dependent fluorescence ratio. Addition of thrombin $(1 \mathrm{U} / \mathrm{ml})$ still caused a significant increase in the ratio. Similar findings were seen in five experiments. sure of $\mathrm{K}^{+}$depolarized aggregates to thrombin causes pronounced quenching of $F_{430}(n=6$; results not shown). This result confirms that thrombin-induced bivalent cation entry is independent of the voltage-sensitive calcium channels. Involvement of the sodium calcium exchange is also excluded for reasons noted above.

Thrombin also causes calcium influx in platelets $(3,30)$, which is insensitive to verapamil but can be blocked by $\mathrm{Ni}^{++}$. We therefore examined the effects of $\mathrm{Ni}^{++}$in heart cell aggregates. Fig. 9 shows a "quenching" experiment similar to Fig. 8 , except the cells are also exposed to $2 \mathrm{mM} \mathrm{Ni}^{++}$before addition of thrombin. Thrombin in the presence of $\mathrm{Ni}^{++}$fails to quench the 430-nm fluorescence (i.e., fails to induce $\mathrm{Mn}^{++}$entry) which indicates that $\mathrm{Ni}^{++}$blocks the thrombin-induced pathway for entry of bivalent cations. To confirm the ability of this method to detect $\mathrm{Mn}^{++}$entry, ionomycin (150 nM) is added at the end of the experiment, which causes rapid quenching of the $F_{430}$ signal.

Thrombin-stimulated calcium release. To examine the possible contribution of internal calcium release to the $\left[\mathrm{Ca}^{++}\right]_{i}$ increase, we have removed external calcium by rapidly exchanging the buffer to one that contains zero calcium and 2 mM EGTA. These experiments are sometimes done in the presence of $10 \mathrm{mM} \mathrm{Li}^{+}$for reasons discussed below. As shown in Fig. 10, calcium removal causes cessation of beating and a slow decline in the calcium-sensitive fluorescence ratio. However, with the addition of thrombin, there is a clear increase in the ratio. The rise in $\left[\mathrm{Ca}^{++}\right]_{\mathrm{i}}$ occurs $36.8 \pm 11.2 \mathrm{~s}(n=4)$ after

IVer $\quad \downarrow \mathrm{Mn}^{++} \downarrow$ Thrombin
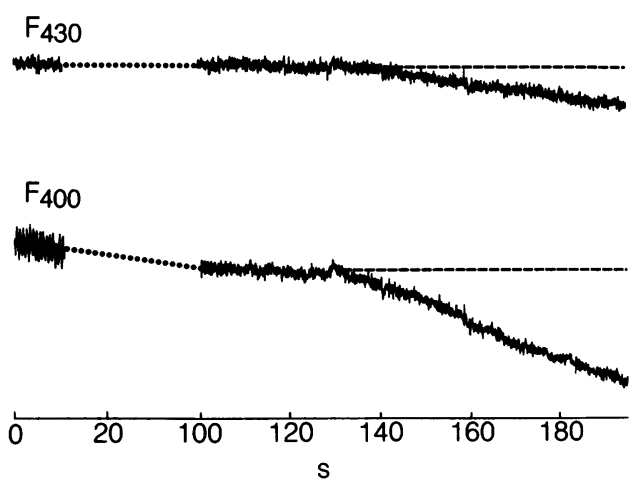

Figure 8. Thrombin-induced calcium influx demonstrated by $\mathrm{Mn}^{++}$ quenching. Spontaneous beating was first abolished by verapamil ( 50 $\mu \mathrm{M})$. Verapamil caused a decrease of the calcium-sensitive $400-\mathrm{nm}$ fluorescence (bottom trace) and abolished the calcium transients, but did not significantly change the calcium-insensitive 430 -nm fluorescence (top trace). Addition of $\mathrm{Mn}^{++}(0.8 \mathrm{mM})$ had no significant effect on either signal. Subsequent addition of thrombin caused rapid quenching of both signals indicating entry of bivalent cations. Similar findings were seen in two other experiments. the addition of thrombin. The absence of external calcium in these experiments is confirmed by the lack of effect on the fluorescence ratio of depolarization of the cells with $30 \mathrm{mM}$ $\mathrm{KCl}$ (data not shown). The effect of thrombin on $\left[\mathrm{Ca}^{++}\right]_{i}$ in the absence of external calcium is smaller and more gradual than in the presence of calcium (Fig. 2). The response is also less sustained and returns to baseline within $80 \mathrm{~s}$. This result implies that external calcium is needed for the sustained phase of the $\left[\mathrm{Ca}^{++}\right]_{i}$ increase. An alternative explanation is that the intracellular calcium store may be partially depleted in zero external calcium so that a more transient $\left[\mathrm{Ca}^{++}\right]_{i}$ increase is observed. Whatever the case, these data show that thrombin can increase $\left[\mathrm{Ca}^{++}\right]_{i}$ in the absence of calcium entry.

Agonist-mediated release of internal calcium is thought to be mediated by $\mathrm{IP}_{3}$. To examine this possibility, we pretreated cell aggregates with $10 \mathrm{mM} \mathrm{LiCl}$ for $10 \mathrm{~min}$ before addition of thrombin. In the presence of external calcium and $\mathrm{Li}^{+}$(Fig. 11, right), there is a trend towards an increase in the effect of thrombin on $\left[\mathrm{Ca}^{++}\right]_{i}$, but this trend does not reach statistical significance ( $n=5$, systolic, $P=0.108$; diastolic, $P=0.132)$. In the absence of external calcium (Fig. 11, left) $\mathrm{Li}^{+}$significantly potentiates the thrombin-induced calcium increase $(n=5, P$ $<0.005$ ). Thus, the effect of $\mathrm{Li}^{+}$is particularly evident when the calcium increase is due to internal release.

We next examined whether $\mathrm{Ni}^{++}$has any effect on thrombin-induced calcium release. In Fig. 12 , verapamil $(50 \mu \mathrm{M})$ is added, causing the cells to become quiescent, with a slow decline in the $F_{400} / F_{550}$ ratio. Addition of $\mathrm{Ni}^{++}(2 \mathrm{mM})$ causes further reduction of the ratio. Addition of thrombin in the continued presence of verapamil and $\mathrm{Ni}^{++}$causes a distinct increase in the ratio that is more gradual than usual, and is similar in time course to that seen in zero external calcium. This result, together with Fig. 9, suggests that $\mathrm{Ni}^{++}$blocks thrombin-induced calcium entry but not intracellular calcium release.

\section{Discussion}

The present study shows that thrombin significantly increases both systolic and diastolic $\left[\mathrm{Ca}^{++}\right]_{i}$ in chick embryonic heart

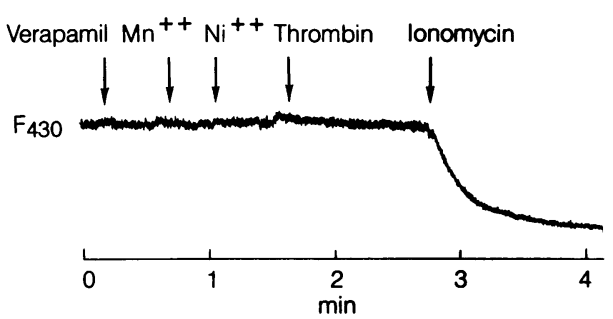

Figure 9 . Inhibition of the calcium influx pathway by $\mathrm{Ni}^{++}$. Same experiment as in Fig. 8 except that $\mathrm{Ni}^{++}(2 \mathrm{mM})$ was added before thrombin. The ability of thrombin to elicit $\mathrm{Mn}^{++}$influx was inhibited by $\mathrm{Ni}^{++}$. As expected, ionomycin $(150 \mathrm{nM})$ caused rapid quenching of the fluorescence signal despite the presence of $\mathrm{Ni}^{++}$. 


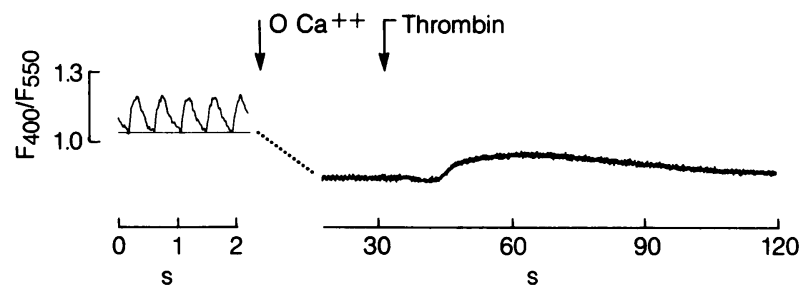

Figure 10. Thrombin-induced increase in $\left[\mathrm{Ca}^{++}\right]_{\mathrm{i}}$ in the absence of external calcium. Cells were treated with $10 \mathrm{mM} \mathrm{Li}^{+}$for 2 min before exchanging the buffer solution to one that contained zero $\mathrm{Ca}^{++} / 2$ mM EGTA. This caused cessation of beating with abolition of the calcium transients and a slow decline of the calcium-dependent fluorescence ratio. Addition of thrombin (arrow) caused a gradual increase in the fluorescence ratio. Similar findings were seen in five experiments.

cells. Associated with the calcium increase, we observed a positive inotropic effect and broadening of the action potential. It appears that the proteolytic activity of thrombin is required for these effects since PPACK, a synthetic peptide which alkylates the histidine residue of the active site of thrombin (18), abolishes the $\left[\mathrm{Ca}^{++}\right]_{i}$ increase. Similarly, Jones et al. (31) have found that in nonbeating chick embryonic heart cells, PPACK-thrombin did not increase $\mathrm{IP}_{3}$ synthesis but served as a competitive inhibitor of the increase in $\mathrm{IP}_{3}$ by thrombin. They also found that an active site-blocked derivative of thrombin was ineffective in stimulating $\mathrm{IP}_{3}$ production (19). The cell cultures used do not consist purely of cardiac myocytes. It was reported that in a similar monolayer culture, there were up to $20 \%$ fibroblasts (10). However, because of the following reasons, we believe the calcium signal we measure is mainly from cardiac myocytes and that the contribution of fibroblasts is small: (a) The inotropic effect, chronotropic effect, and the prolongation of action potential duration observed concomitantly with the $\left[\mathrm{Ca}^{++}\right]_{i}$ increase are myocyte specific. (b) There is an increase in the net amplitude of the calcium transient from a mean value of $293 \pm 35$ to $454 \pm 63$ nM ( $n=6, P<0.05)$ with the addition of thrombin. Any thrombin induced fluorescence change arising from fibroblasts would shift the diastolic baseline, but would not change the

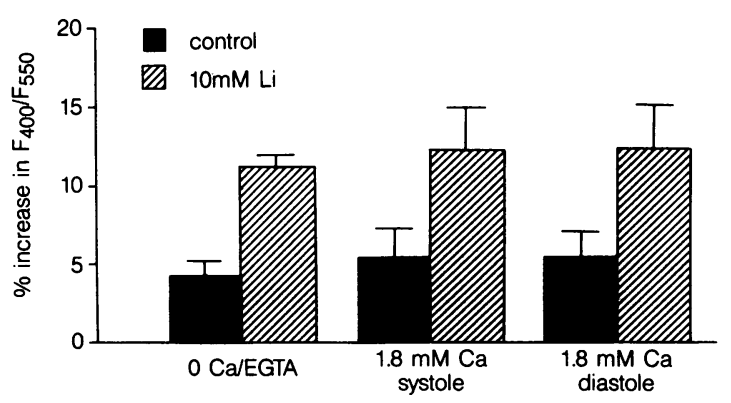

Figure 11. Effect of $\mathrm{Li}^{+}$on the thrombin-induced $\left[\mathrm{Ca}^{++}\right]_{\mathrm{i}}$ increase. Striped bars indicate cells treated with $10 \mathrm{mM} \mathrm{Li}^{+}$for 2 min before addition of thrombin. Five cell aggregates were studied in the presence and five in the absence of external calcium. $\mathrm{Li}^{+}$potentiated the thrombin-induced $\left[\mathrm{Ca}^{++}\right]_{i}$ increase in both conditions but the difference only reached statistical significance in the absence of external calcium (zero $\mathrm{Ca}^{++}, P<0.005 ; 1.8 \mathrm{mM} \mathrm{Ca}^{++}$, systolic, $P=0.108$; diastolic, $P=0.132$ ) amplitude of calcium transients as observed here. (c) Bradykinin $(0.1 \mathrm{mM})$ which is known to increase $\left[\mathrm{Ca}^{++}\right]_{\mathrm{i}}$ in fibroblasts (32), has no effect on the calcium signal in our system while subsequent addition of thrombin causes a significant calcium increase.

Although the chronotropic effect of thrombin will increase diastolic and systolic $\left[\mathrm{Ca}^{++}\right]_{i}$ by the staircase phenomenon (11), the $\left[\mathrm{Ca}^{++}\right]_{i}$ increase we observe is too large to be explained by the small increase in beat frequency alone. Also in some of our experiments, thrombin caused a significant increase in $\left[\mathrm{Ca}^{++}\right]_{\mathrm{i}}$ without significantly changing the beat frequency. Thus, thrombin can cause $\left[\mathrm{Ca}^{++}\right]_{\mathrm{i}}$ increase and have an inotropic effect independent of its effect on beat frequency.

The quantitative increase in $\left[\mathrm{Ca}^{++}\right]_{i}$ that we obtain is similar to that reported for other inotropes. There are some inherent limitations in the calibration of indo-1 fluorescence including partially de-esterified dye, compartmentation, bleaching, and the loss of dye during the course of experiments. However, the values of $\left[\mathrm{Ca}^{++}\right]_{i}$ that we obtained were in the range of what other laboratories find using fura- 2 free acid injected by pipette (33) or $\mathrm{Ca}^{++}$-sensitive electrodes (34). Furthermore, none of the possible errors in calibration would invalidate the qualitative observations upon which our principal conclusions are based.

Our experiments show that thrombin induces simultaneous influx of calcium and intracellular release. From the $\mathrm{Mn}^{++}$-quenching experiments, it appears that calcium entry begins early in relation to the $\left[\mathrm{Ca}^{++}\right]_{i}$ increase. We did not see any increase in $\left[\mathrm{Ca}^{++}\right]_{i}$ before $\mathrm{Mn}^{++}$entry, but calcium release could still be an important component of the initial increase in $\left[\mathrm{Ca}^{++}\right]_{\mathrm{i}}$. Using stopped-flow fluorimetric measurements, Sage et al. (35) have shown that in platelets, thrombin-induced calcium entry slightly precedes internal release. Sustained calcium entry maintains $\left[\mathrm{Ca}^{++}\right]_{i}$ at a plateau level after internal release is completed. Our data are in agreement with these findings and show that the thrombin-induced $\mathrm{Mn}^{++}$entry persists in the presence of thrombin (Fig. 8) and that external calcium may be needed for the sustained phase of the $\left[\mathrm{Ca}^{++}\right]_{i}$ increase (Fig. 2).

Second messenger cascade. Thrombin has been shown to activate phospholipase $\mathrm{C}$ and thus increase $\mathrm{IP}_{3}$ in a variety of cell types (20-22), including chick embryonic heart cells (19). Our work confirms this finding, and shows that $\mathrm{IP}_{3}$ formation occurs early enough to play a causative role in the $\left[\mathrm{Ca}^{++}\right]_{i}$ increase. The peak increase in $\mathrm{IP}_{3}$ is delayed relative to the peak increase in $\left[\mathrm{Ca}^{++}\right]_{\mathrm{i}}$ (observed in normal external calcium). However, the onset of the $\left[\mathrm{Ca}^{++}\right]_{i}$ and $\mathrm{IP}_{3}$ increases are roughly coincident.

Our measurements of the $\mathrm{IP}_{3}$ time course are in agreement with those of Jones et al. (31), who also studied chick embryonic myocytes. However these investigators saw no significant increase in $\left[\mathrm{Ca}^{++}\right]_{i}$. One possible reason for this difference is that the myocardial cell aggregates which we used had been maintained in cultures for 3-5 d, which is known to restore various channel and receptor functions compared to the cells which Jones et al. (31) employed which were cultured overnight.

Our results with pertussis toxin suggest that the activation of phospholipase $\mathrm{C}$ by thrombin is coupled to a pertussis toxin-sensitive $G$ protein. A similar pertussis toxin-sensitive $G$ protein coupling phospholipase $\mathrm{C}$ to thrombin receptors has been demonstrated in platelets (21), fibroblasts (22), and 


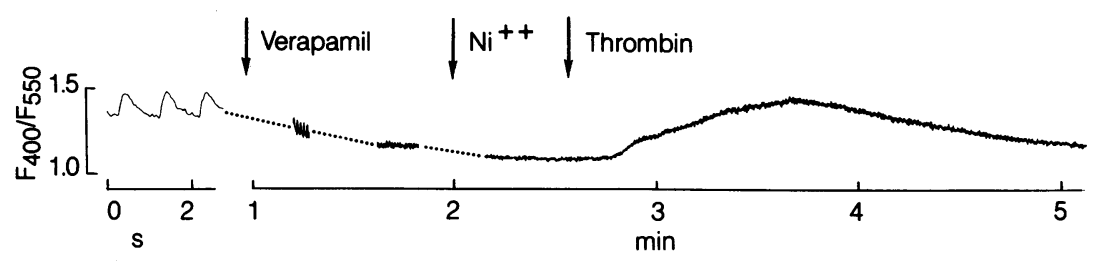

Figure 12. Thrombin-induced $\left[\mathrm{Ca}^{++}\right]_{\mathrm{i}}$ increase in the presence of $\mathrm{Ni}^{++}$and verapamil. The cell aggregate was first treated with verapamil, which caused it to stop beating, and then with $\mathrm{Ni}^{++}$. Subsequent addition of thrombin caused a significant increase in the fluorescence ratio despite the presence of verapamil $(50 \mu \mathrm{M})$ and $\mathrm{Ni}^{++}(2 \mathrm{mM})$. This recording is representative of three experiments. smooth muscle cells (2). A pertussis toxin-sensitive $G$ protein that is coupled to the muscarinic receptor has also been shown in chick heart cells $(25,26)$ although the $G$ protein that regulates carbachol-induced $\mathrm{IP}_{3}$ formation in these cells is pertussis toxin-insensitive. Thus different receptors may utilize different $G$ proteins to carry out the same function (36).

Receptor-operated calcium channels. We have also demonstrated that there is receptor-mediated entry of calcium into embryonic myocytes that is not dependent on depolarization. Absence of action potentials in verapamil-treated cells is inferred from the cessation of calcium transients, and has been confirmed in several cell aggregates by intracellular recording. A similar thrombin-induced calcium entry that is verapamilinsensitive, but blocked by $\mathrm{Ni}^{++}$has been demonstrated in platelets by the $\mathrm{Mn}^{++}$-quenching technique (3). Furthermore, thrombin has been shown to cause the activation of unique calcium ion channels in the membrane of human platelets (30). These presumed receptor-operated channels are insensitive to voltage and are not inhibited by organic calcium channel blockers, but they are blocked by nickel. While receptor operated channels have not been described in cardiac myocytes, our results strongly indicate that a thrombin-activated channel may exist.

Since pertussis toxin inhibits the $\left[\mathrm{Ca}^{++}\right]_{\mathrm{i}}$ increase, it is likely that the calcium influx pathway is regulated by a pertussis toxin-sensitive $G$ protein. There are three ways in which this regulation might occur. First, $G$ protein molecules activated by the thrombin receptor may interact directly with the putative calcium channel. Other ligand-regulated channels, such as the voltage-dependent calcium channel are gated by $G$ protein-coupled receptors in this way $(37,38)$. Secondly, it is possible that the calcium channel is activated by $I P_{3}$. Since thrombin-stimulated $\mathrm{IP}_{3}$ production is inhibited by pertussis toxin, the toxin would be expected to inhibit calcium entry. An $\mathrm{IP}_{3}$-regulated calcium channel has been reported to exist in $\mathrm{T}$ lymphocytes (39), although this channel has very different properties than the thrombin-activated calcium channel in platelets (27). Finally, it has been proposed (40) that the emptying of $\mathrm{IP}_{3}$-sensitive intracellular calcium stores directly stimulates calcium influx from the extracellular space. Any of the above mechanisms would be compatible with our results.

Our results are partly at variance with the work of Markwardt et al. (7), who showed that thrombin enhanced the slow inward calcium current in voltage clamped frog ventricular cells. This effect was blocked by verapamil. Since we could not clamp the slow inward current in our cell aggregates, we cannot exclude that thrombin stimulates calcium entry through L-type channels in addition to receptor-operated channels.

Implication for disease states. The concentration of thrombin $(1 \mathrm{U} / \mathrm{ml})$ we used in these experiments is in the range used by other investigators $(2,3,19)$. Although the normal concentration of thrombin in the blood and extracellular space is unknown, the local concentration is likely to be increased in conditions that promote thrombosis, such as ischemic heart disease or any condition that disrupts the endothelium and activates coagulation (e.g., balloon angioplasty). Since cytoplasmic calcium overload in cardiac cells is thought to play an important role in ischemic arrhythmias (41) and reperfusion injury (42), the increase of $\left[\mathrm{Ca}^{++}\right]_{i}$ by thrombin may be of physiological importance under these conditions.

In summary, our data suggest that in chick embryonic heart cells, thrombin increases $\left[\mathrm{Ca}^{++}\right]_{\mathrm{i}}$ by mechanisms involving calcium entry via a receptor-operated/voltage-independent pathway and intracellular calcium release associated with $\mathrm{IP}_{3}$ synthesis. Both of these events may be linked to a pertussis toxin-sensitive $\mathrm{G}$ protein.

\section{Acknowledgments}

We thank Drs. Larry Leung and Brian Hoffman for their helpful comments and Rita Petriceks for her expert technical assistance in cell culture.

Dr. Chien was a Merck Fellow of the American College of Cardiology, 1988-89. Dr. Mohabir is the recipient of a Canadian Heart Foundation Fellowship. Dr. Clusin is an Established Investigator of the American Heart Association.

\section{References}

1. Chen, L. B., and J. M. Buchanan. 1975. Mitogenic activity of blood components I. Thrombin and prothrombin. Proc. Natl. Acad. Sci. USA. 72:131-135.

2. Haung, C. L., and H. E. Ives. 1989. Guanosine 5'-O-(3-thiotrisphosphate) potentiates both thrombin- and platelet-derived growth factor-induced inositol phosphate release in vascular smooth muscle cells. J. Biol. Chem. 264:4391-4397.

3. Sage, S. O., J. E. Merritt, T. J. Hallam, and T. J. Rink. 1989. Receptor-mediated calcium entry in fura-2-loaded human platelets stimulated with ADP and thrombin. Biochem. J. 258:923-926.

4. Hallam, T. J., and T. J. Rink. 1989. Receptor-mediated $\mathrm{Ca}^{2+}$ entry: diversity of function and mechanism. Trends Pharmcol. Sci. 10:8-10.

5. Haung, C. L., M. G. Cogan, E. J. Cragoe, Jr., and H. E. Ives. 1988. Thrombin activation of the $\mathrm{Na}^{+} / \mathrm{H}^{+}$exchanger in vascular smooth muscle cells. J. Biol. Chem. 262:14134-14140.

6. Gilman, A. G. 1987. G proteins: transducers of receptor-generated signals. Annu. Rev. Biochem. 56:615-649.

7. Markwardt, F., R. Albitz, T. Franke, and B. Nilius. 1988 Thrombin stimulates Ca-channel currents in isolated frog ventricular cells. Pflügers Arch. Eur. J. Physiol. 412:668-670.

8. Clusin, W. T. 1981. The mechanical activity of chick embryonic myocardial cell aggregates. J. Physiol. (Lond.). 320:149-174.

9. Lee, H. C., and W. T. Clusin. 1989. Effect of BAY K8644 on cytosolic calcium transients and contraction in embryonic cardiac ventricular myocytes. Pflügers Arch. Eur. J. Physiol. 413:225-233.

10. Peeters, G. A., V. Hlady, J. H. B. Bridge, and W. H. Barry. 
1987. Simultaneous measurement of calcium transients and motion in cultured heart cells. Am. J. Physiol. 252:H1400-1408.

11. Lee, H. C., and W. T. Clusin. 1987. Cytosolic calcium staircase in culture myocardial cells. Circ. Res. 61:934-939.

12. Hesketh, T. R., G. A. Smith, J. P. Moore, M. Taylor, and J. C. Metcalfe. 1983. Free cytoplasmic calcium concentration and mitogenic stimulation of lymphocytes. J. Biol. Chem. 258:4876-4882.

13. Tsien, R. Y., T. Pozzan, and T. J. Rinks. 1982. Calcium homeostasis in intact lymphocytes: cytoplasmic free calcium monitored with a new intracellularly trapped indicator. J. Cell Biol. 94:325-334.

14. Jones, L. G., D. Goldstein, and J. H. Brown. 1988. Guanine nucleotide-dependent inositol trisphosphate formation in chick heart cells. Circ. Res. 62:299-305.

15. Berridge, M. J., C. P. Downes, and M. R. Hanley. 1982. Lithium amplifies agonist-dependent phosphatidylinositol responses in brain and salivary gland. Biochem. J. 206:587-595.

16. Batty, I. R., S. R. Nahorski, and R. F. Irvine. 1985. Rapid formation of inositol 1,3,4,5-tetrakisphosphate. Biochem. J. 232:211215 .

17. Lowry, O. H., N. J. Rosenbrough, A. L. Farr, and R. J. Randall. 1951. Protein measurement with the Folin phenol reagent. J. Biol. Chem. 265:265-275.

18. Kettner, C., and E. Shaw. 1979. D-phe-pro-argCH${ }_{2} \mathrm{Cl}-$ a selective affinity label for thrombin. Thromb. Res. 14:969-973.

19. Jones, L. G., and J. H. Brown. 1986. Stimulation of phosphoinositide hydrolysis by thrombin in embryonic chick heart cells. Fed. Proc. 45:930. (Abstr.)

20. Brass, L. F., M. Laposata, H. S. Banga, and S. Rittenhouse. 1986. Regulation of the phosphoinostide hydrolysis pathway in thrombin-stimulated platelets by a pertussis toxin-sensitive guanine nucleotide-binding protein. J. Biol. Chem. 261:16838-16847.

21. Chambard, J. C., S. Paris, G. L'Allemain, and J. Pouyssegur. 1987. Two growth factor signalling pathways in fibroblasts distinguished by pertussis toxin. Nature (Lond.). 326:800-803.

22. Paris, G., and J. Pouyssegur. 1986. Pertussis toxin inhibits thrombin-induced activation of phosphoinositide hydrolysis and $\mathrm{Na}^{+} / \mathrm{H}^{+}$exchange in hamster fibroblast. EMBO (Eur. Mol. Biol. Organ.) J. 5:55-60.

23. Berridge, M. J., and R. F. Irvine. 1984. Inositol trisphosphate, a novel second messenger in cellular signal transduction. Nature (Lond.). 312:315-321.

24. Drummond, A. H., L. A. Joels, and P. J. Hughes. 1987. The interaction of lithium ions with inositol lipid signalling systems. Biochem. Soc. Trans. 15:32-35.

25. Liang, B. T., M. R. Hellmrich, E. J. Neer, and J. B. Galper. 1986. Development of muscarinic cholinergic inhibition of adenylate cyclase in embryonic chick heart. J. Biol. Chem. 261:9011-9021.

26. Martin, J. M., D. D. Hunter, and N. M. Nathanson. 1985. Islet activating protein inhibits physiological responses evoked by cardiac muscarinic acetylcholine receptors: role of guanosine triphosphate binding proteins in regulation of potassium permeability. Biochemistry. 24:7521-7525.

27. Hallam, T. J., and T. J. Rink. 1985. Agonist stimulates divalent cation channels in the plasma membrane of human platelets. FEBS (Fed. Eur. Biochem. Soc.) Lett. 186:175-179.

28. Grynkiewicz, G., M. Poenie, and R. Y. Tsien. 1985. A new generation of $\mathrm{Ca}^{2+}$ indicators with greatly improved fluorescence properties. J. Biol. Chem. 260:3440-3450.

29. Lee, H. C., and W. T. Clusin. 1987. $\mathrm{Na}^{+} / \mathrm{Ca}^{++}$exchange in cardiac myocytes: effect of ouabain on voltage dependence. Biophys. J. 51:169-176.

30. Zschauer, A., C. van Breeman, F. R. Buhler, and M. T. Nelson. 1988. Calcium channels in thrombin-activated human platelet membrane. Nature (Lond.). 334:703-705.

31. Jones, L. G., P. M. McDonough, and J. H. Brown. 1989. Thrombin and trypsin act at the same site to stimulate phosphoinositide hydrolysis and calcium mobilization. Mol. Pharmacol. 36:142149.

32. Palfrey, H. C., A. C. Nairn, L. L. Muldoon, and M. L. Villereal. 1987. Rapid activation of calmodulin-dependent protein kinase III in mitogen-stimulated human fibroblasts. J. Biol. Chem. 262:9785-9792.

33. Cannell, M. B., J. R. Berlin, W. J. Lederer. 1987. Effect of membrane potential changes on the calcium transient in single rat cardiac cells. Science (Wash. DC). 238:1419-1423.

34. Marban, E., T. J. Rink, R. W. Tsien, and R. Y. Tsien. 1980. Free calcium in heart muscle at rest and during contraction measured with $\mathrm{Ca}^{++}$sensitive microelectrodes. Nature (Lond.). 286:845-850.

35. Sage, S. O. 1987. Kinetics of ADP-evoked and thrombinevoked rises in cytosolic calcium in human platelets: studies with manganese and nickel. J. Physiol. (Lond.). 396:43P.

36. Ashkenazi, A., E. G. Peralta, J. W. Winslow, J. Ramachandran, and D. J. Capon. 1989. Functionally distinct $G$ proteins selectively couple different receptors to PI hydrolysis in the same cell. Cell. $56: 487-493$.

37. Rosenthal, W., J. Hescheler, W. Trautwein, and G. Shultz. 1988. Control of voltage-dependent $\mathrm{Ca}^{++}$channel by $\mathrm{G}$ protein-coupled receptors. FASEB (Fed. Am. Soc. Exp. Biol.) J. 2:2784-2790.

38. Yatani, A., J. Codina, Y. Imoto, J. P. Reeves, L. Birnbaumer, and A. M. Brown. 1987. A G protein directly regulates mammalian cardiac channels. Science (Wash. DC). 238:1288-1292.

39. Kuno, M., and P. Gardner. 1987. Ion channels activated by inositol 1,4,5-trisphosphate in plasma membrane of human T-lymphocyte. Nature (Lond.). 326:301-304.

40. Putney, J. W., Jr. 1986. A model for receptor-regulated calcium entry. Cell Calcium. 7:1-12.

41. Lee, H. C., R. Mohabir, N. Smith, M. R. Franz, and W. T. Clusin. 1988. Effect of ischemia on calcium dependent fluorescence transients in rabbit hearts containing indo-1; correlation with monophasic action potentials and contraction. Circulation. 78:1047-1059.

42. Naylor, W. G., and J. S. Ely. 1986. Reperfusion injury: laboratory artifact or clinical dilemma. Circulation. 74:215-221. 